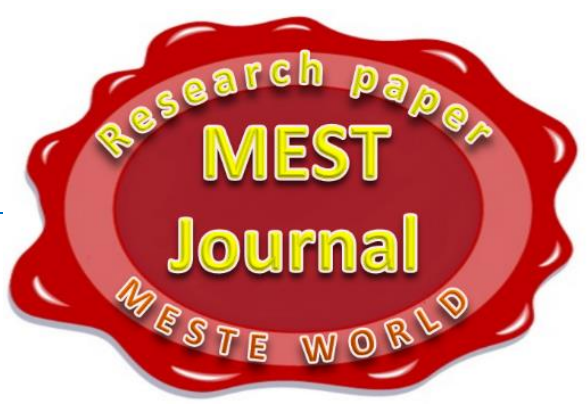

\title{
HUMAN CAPITAL DEPRECIATION OF FEMALE IMMIGRANTS AND WAYS TO RESTORE LOST HUMAN CAPITAL
}

\section{Oksana Koshulko \\ Polotsk State University, Department of Finance and Industrial Economics, Novopolotsk, Belarus}

CMESTE

JEL Category: F2, F22, J6, J61, R2, R23

\begin{abstract}
This paper presents the results of research on female immigration from the former Soviet Union conducted in the 2014-2015 academic years in the cities of Antalya, Istanbul, and Izmir in Turkey. The article also presents an explanation of the terms "Human capital depreciation" and "human capital restoration (or recovery)" as they apply to female immigrants from the countries of the former Soviet Union in Turkey. The article shows the educational level of female immigrants from the former Soviet Union, their difficulties in obtaining recognition of their academic diplomas, their opportunities, and desires concerning the continuation their education or of moving into higher education in Turkey as a means of restoration of their Human capital in that country. The following definitions also apply in this paper such as 'basic and professional human capital'. Conclusions about the prevention of Human capital depreciation and the restoration of Human capital for female immigrants are included in the paper.
\end{abstract}

Keywords: Basic and professional human capital, depreciation, restoration, Turkey, female immigrants, Soviet Union

\section{INTRODUCTION}

During recent years I have studied Human capital depreciation and the opportunities for Human capital restoration of female immigrants in my previous papers "Exploring of the Human Capital Depreciation of Ukrainian Labor Migrants Abroad: Results of a Survey" (Koshulko, 2015a), and "Issues in countries of the former Soviet Union as

\section{Address of the author: \\ Oksana Koshulko \\ 麦=" oksanakoshulko2015@gmail.com}

the driving force for female migration to Turkey" (Koshulko, 2015b), in a book "Women from North move to South: Contemporary migration from the Former Soviet Union countries to Turkey" (Koshulko, 2016a), and in the essay "Discourse about Women-Immigrants from Former Soviet Union Countries as a Special Social Group in Turkey" (Koshulko, 2016b). The basis for analysis of terms "Human capital depreciation" and "Human capital restoration" are papers by $\mathrm{M}$. Arrazola and J. Hevia (Arrazola \& Hevia, 2004); K. Hollenbeck (Hollenbeck, 1990); D. McFadden 
(McFadden, 2008); J. Mincer and H. Ofek (Mincer \& Ofek, 1982), and other scientists.

In this paper I would like to explore the educational level of female immigrants from the former Soviet Union in Turkey, their difficulties in obtaining recognition of their academic diplomas and their opportunities and desires for the continuation of their education or of moving into higher education in Turkey as a means of restoring their Human capital.

\section{METHODOLOGY OF THE RESEARCH}

The methodology of the research consisted of quantitative and qualitative methods. Quantitative methods consisted of objective measurement and the statistical and numerical analysis of data collected through surveys. The qualitative research consisted of semi-structured interviews, generally referred to as 'conversation with a purpose'.

The strategy of the research consisted of the following stages: collecting data through surveys and semi-structured interviews; creating a database using the responses; the statistical and numerical analysis of this data.

The sample for research was taken from female immigrants from the former Soviet Union in Turkey, who came to that country for a variety of reasons. I aimed to discover their educational level, their problems obtaining recognition of their academic diplomas and their opportunities and desires in respect of the continuation their education or of moving into higher education in Turkey in order to restore their lost Human capital.

More than 400 respondents - female immigrants from the former Soviet Union in Turkey participated in the surveys and semi-structured interviews in Turkey. The sample for my research was taken from female immigrants from the former Soviet Union in Istanbul, Antalya, and Izmir. The sample consisted of female immigrants from the former Soviet Union in Turkey. However, no method of sampling can truly represent all the female immigrants from the former Soviet Union in Turkey and the resulting margin of error is known as a sampling error.

\section{THE APPEARANCE OF THE TERM 'HUMAN CAPITAL' IN SCIENCE}

The term 'Human Capital' appeared in the 1960s in the USA and it means talents, knowledge, skills and the generation of ideas of people for scientific and technical progress in the world. The founders of the theory of Human Capital were American scientists, recipients of the Nobel Prize in Economic Sciences, Theodore William Schultz and Gary Stanley Becker. According to data Investopedia, the economist Theodore William Schultz invented the term "human capital" in the 1960s to reflect the value of human capacities (Schultz, 1961). He believed human capital was like any other type of capital; it could be invested in through education, training and enhanced benefits that lead to an improvement in the quality and level of production" (Investopedia, 2016).

According to data from the University of Chicago Press, Gary Stanley Becker, author of the book "A Theoretical and Empirical Analysis, with Special Reference to Education" (Becker, 1993), is "a pioneer of applying economic analysis to human behavior in such areas as discrimination, marriage, family relations, and education" (University of Chicago Press, 2016).

\section{EDUCATIONAL LEVEL OF FEMALE IMMIGRANTS FROM THE FORMER SOVIET UNION IN TURKEY}

I also studied some issues of human capital in my thesis "Human Capital Management in the Retail Food Industry" (Koshulko, 2008) and in the book "Women from North move to South: Contemporary migration from the Former Soviet Union countries to Turkey" (Koshulko, 2016a). In my opinion, the human capital of female immigrants from the former Soviet Union, who come to Turkey for various reasons, is a very valuable commodity for any country and this capital is of particular value in the development of society and the economy. Female immigrants who have university degrees have valuable human capital and they need to continue the development of their careers and their human capital. The results of my research show that a large 
percentage of female immigrants from the former Soviet Union in Turkey have Ph.D. degrees and universities degrees (Table 1).

Table 1. Showing the educational level of female immigrants from the former Soviet Union in Turkey

\begin{tabular}{|c|c|c|c|c|}
\hline Countries & 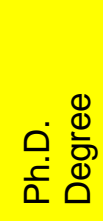 & $\begin{array}{l}\frac{0}{\pi} \\
\frac{\pi}{0} \\
\frac{0}{0} \\
\frac{\pi}{0} \\
\mathbb{U} \\
\mathbb{0}\end{array}$ & $\begin{array}{l}\mathscr{\Phi} \\
\Phi \\
\bar{O} \overline{0} \\
\end{array}$ & 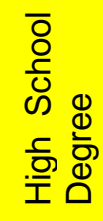 \\
\hline Armenia & 0 & $100 \%$ & 0 & 0 \\
\hline Azerbaijan & $14 \%$ & $72 \%$ & $7 \%$ & $7 \%$ \\
\hline Belarus & 0 & $76 \%$ & $20 \%$ & $4 \%$ \\
\hline Estonia & 0 & $100 \%$ & 0 & 0 \\
\hline Georgia & 0 & $22 \%$ & $22 \%$ & $56 \%$ \\
\hline Kazakhstan & 8 & $62 \%$ & $15 \%$ & $15 \%$ \\
\hline Kyrgyzstan & 0 & $55 \%$ & $27 \%$ & $18 \%$ \\
\hline Latvia & 0 & $100 \%$ & 0 & 0 \\
\hline Lithuania & $17 \%$ & $83 \%$ & 0 & 0 \\
\hline Moldova & $5 \%$ & $50 \%$ & $35 \%$ & $10 \%$ \\
\hline Russia & $4 \%$ & $76 \%$ & $13 \%$ & $7 \%$ \\
\hline Tajikistan & 0 & $100 \%$ & 0 & 0 \\
\hline Turkmenistan & $10 \%$ & $36 \%$ & $36 \%$ & $18 \%$ \\
\hline Ukraine & $5 \%$ & $65 \%$ & $12 \%$ & $18 \%$ \\
\hline Uzbekistan & 0 & $57 \%$ & $29 \%$ & $14 \%$ \\
\hline
\end{tabular}

Source: Data collected via own research in Turkey (2014-2015)

Of course, the level of education of female immigrants from the former Soviet Union in Turkey differs depending on their country of origin. For example, the educational level of interviewed female immigrants from Estonia or Latvia is generally higher than that of female immigrants from other countries.

The highest educational level is that of female immigrants from Lithuania $(17 \%$ of female immigrants from Lithuania were with Ph.D. degree); Azerbaijan (14\%); Turkmenistan (10\%); Kazakhstan (8\%); Ukraine (5\%); Moldova (5\%); and Russia (4\%). In these cases, one can say with confidence that the educational level of the female immigrants is a very high.
Regarding graduate degrees, from my research in Turkey, I can say that $100 \%$ of interviewed female immigrants from Armenia have a graduate degree; $72 \%$ of Azerbaijani; $76 \%$ of Belarusian; $100 \%$ of Estonian, $100 \%$ of Latvian and $83 \%$ of Lithuanian women; $22 \%$ of Georgian, $62 \%$ of Kazakhstani and $55 \%$ of Kyrgyz female immigrants; $50 \%$ of Moldovan and $76 \%$ of Russian female immigrants; $100 \%$ of female immigrants from Tajikistan; $36 \%$ of Turkmen, $65 \%$ of Ukrainian and $57 \%$ of Uzbek female immigrants.

However, only a small percentage of female immigrants are able to use their education fully in Turkey. The results of surveys and semistructured interviews show that only $20 \%$ of Armenian female immigrants work in their own professions, $29 \%$ of Azerbaijani, $12 \%$ of Belarusian, $25 \%$ of Latvian, $17 \%$ of Lithuanian, $33 \%$ of Georgian, $23 \%$ of Kazakhstani, $18 \%$ of Kyrgyz, $15 \%$ of Moldovan, $18 \%$ of Russian, $27 \%$ of Turkmen, $16 \%$ of Ukrainian, and $14 \%$ of Uzbek female immigrants.

\section{HUMAN CAPITAL DEPRECIATION OF FEMALE IMMIGRANTS}

What is human capital depreciation? What causes human capital to depreciate? According to data from Investopedia, 'human capital depreciation is directly caused by interruptions in a work career, such as periods of unemployment' (Investopedia, 2016).

I studied the human capital depreciation of immigrants in my article "Exploring of the Human Capital Depreciation of Ukrainian Labor Migrants Abroad: Results of a Survey", and from the results of my research I concluded that when skilled workers, for whatever reason, are forced to move abroad and to work as unskilled workers, there is a big problem of Brain Waste for all sides: "... when skilled workers, for whatever reasons, are forced to move abroad and to work as unskilled workers, there is a very big problem of Brain Waste for all sides, for skilled workers, who were professionals in the past, for their country of origin and for their host countries too. Very often these skilled workers, professionals in the past, when they return to their country of origin, find that they cannot work in their previous professions, which is a worse situation for them. Of course, during a 
period of labor migration abroad, labor migrants, professionals in the past, can develop new skills and knowledge, but, unfortunately, labor migrants often perform unskilled work abroad. In my opinion, the biggest problems for skilled workers seeking work as professionals in host countries are language barriers, problems with confirmation of diplomas in host countries, lack of competitive knowledge and skills on international labor markets" (Koshulko, 2015a).

I met numerous female immigrants who work in jobs other than their own professions in Turkey, from translators and teachers of Russian to cleaners and sales-people. Of course, due to life situations, many female immigrants have changed profession in Turkey. I met a lot of female immigrants who no longer worked in their own professions due to various circumstances in their lives. In these cases, their professional human capital cannot develop, and this constitutes Brain Waste, which after some time will become the human capital depreciation of their professional skills and knowledge. These female immigrants will not be able to return to work in their professions nor will they be able to work in more junior positions.

\section{RESTORATION HUMAN CAPITAL OF FEMALE IMMIGRANTS}

I found the term "restoration" of human capital in the article "Interrupted Work Careers: Depreciation and Restoration of Human Capital" (Mincer \& Ofek, 1982) by J. Mincer and H. Ofek, where the authors used this term for exploring restoration of human capital of immigrants.

In a paper by K. Hollenbeck "Dislocated Worker Human Capital Depreciation and Recovery" (Hollenbeck, 1990), the author used another term "Recovery" of human capital, but all the authors agreed that Human Capital needs to be used effectively everywhere in order to prevent Human capital depreciation.

In this paper, I use the term to explore the human capital of female immigrants in Turkey.

If female immigrants cannot work in their professions, how can they restore their human capital in Turkey?
The majority of female immigrants, who come to Turkey for various reasons, would prefer to work, study, and develop their human capital in any area of the economy. If they are in a situation where they cannot work in their professions, they try to enter new professions, to do unskilled jobs or to find other spheres of fulfillment for their human capital, which may help to restore their human capital. In my opinion, they should also gain recognition of their academic diplomas and continue their education in their new country.

\section{RECOGNITION OF ACADEMIC DIPLOMAS}

In Turkey, there is a problem of recognition of the academic diplomas of female immigrants. The procedure of recognition of academic diplomas of foreigners can be done at the Council of Higher Education in Ankara, but not all female immigrants can complete this procedure of recognition for many reasons:

- Because the recognition of academic diplomas can take up to year or more;

- Because of the language barrier in cases where applicants need to pass tests or exams in the Turkish language;

- Because of lack of support from husbands and/or relatives in this issue;

- Because of periods of maternity leave;

- Or other issues.

Courses TOMER at the Turkish and Foreign Languages Research and Application Center of Ankara University or in its branches in Samsun, Marmaris, Izmir, Bursa, Antalya, Istanbul, Trabzon, Giresun, and Alanya can help female immigrants improve their knowledge of Turkish and so gain recognition of their academic diplomas faster and more easily.

In cases where female immigrants do not try to get recognition of their diplomas in Turkey and do not try to find a job in their own professions, they may lose their human capital and professional knowledge and skills as time passes. My previous research shows that for every 12-month period educated and skilled immigrants (male and female) will lose around $1.2 \%$ of their existing Human Capital (Koshulko, 2015a) if they cannot maintain it in Turkey. 
8 OPPORTUNITIES AND DESIRES TO MOVE ON TO HIGHER EDUCATION IN TURKEY

During my research in Turkey, I asked female immigrants about their opportunities and their desires to continue their education. From their replies, I conclude that not all of them are able to study even if they have the desire to do so.

Table 2 shows the responses of female immigrants from the former Soviet Union in Turkey.

Table 2. Showing responses of female immigrants from the former Soviet Union in Turkey about their opportunities and desires to continue their education

\begin{tabular}{|l|r|r|r|r|}
\hline Countries & \multicolumn{2}{|l|}{$\begin{array}{l}\text { Opportunity to } \\
\text { continue } \\
\text { education } \\
\text { (parts out of } \\
100 \%)\end{array}$} & $\begin{array}{l}\text { Desire } \\
\text { continue } \\
\text { education } \\
\text { (parts out of } \\
100 \%)\end{array}$ \\
\cline { 2 - 5 } Yes & No & \multicolumn{1}{l|}{ Yes } & \multicolumn{1}{l|}{ No } \\
\hline Armenia & $60 \%$ & $20 \%$ & $20 \%$ & $80 \%$ \\
\hline Azerbaijan & $86 \%$ & $14 \%$ & $64 \%$ & $36 \%$ \\
\hline Belarus & $56 \%$ & $40 \%$ & $72 \%$ & $28 \%$ \\
\hline Estonia & $100 \%$ & 0 & $100 \%$ & 0 \\
\hline Georgia & $11 \%$ & $89 \%$ & $11 \%$ & $89 \%$ \\
\hline Kazakhstan & $46 \%$ & $54 \%$ & $46 \%$ & $54 \%$ \\
\hline Kyrgyzstan & $64 \%$ & $36 \%$ & $36 \%$ & $64 \%$ \\
\hline Latvia & $100 \%$ & 0 & $100 \%$ & 0 \\
\hline Lithuania & $67 \%$ & $33 \%$ & $50 \%$ & $50 \%$ \\
\hline Moldova & $60 \%$ & $40 \%$ & $75 \%$ & $25 \%$ \\
\hline Russia & $66 \%$ & $34 \%$ & $61 \%$ & $39 \%$ \\
\hline Tajikistan & $50 \%$ & $50 \%$ & $100 \%$ & 0 \\
\hline Turkmenistan & $27 \%$ & $73 \%$ & $36 \%$ & $64 \%$ \\
\hline Ukraine & $51 \%$ & $49 \%$ & $55 \%$ & $45 \%$ \\
\hline Uzbekistan & $29 \%$ & $71 \%$ & $71 \%$ & $29 \%$ \\
\hline
\end{tabular}

Source: Data collected via own research in

Turkey (2014-2015)

From the data in Table 2 that I collected during my research on female immigrants in Turkey, I conclude that $60 \%$ Armenian female immigrants have opportunities to continue their education, but only $20 \%$ of them have the desire to do so $(20 \%$ of Armenian female immigrants did not respond).

Azerbaijani female immigrants - $86 \%$ of them have opportunities to continue their education and $64 \%$ of them have the desire to do so.

Belarusian - $56 \%$ of them have opportunities and $72 \%$ of them have the desire to do so.

Estonian, Latvian and Lithuanian female immigrants show that $-100 \%$ of all interviewed Estonian, $100 \%$ of Latvian and $67 \%$ of Lithuanian female immigrants have opportunities and $100 \%$ of all interviewed Estonian, 100\% of Latvian and $50 \%$ of Lithuanian female immigrants have the desire to do so.

Georgian, Kazakhstani, and Kyrgyz - 33\% of Georgian, $54 \%$ of Kazakhstani and $91 \%$ of Kyrgyz female immigrants have opportunities and $11 \%$ of Georgian, $46 \%$ of Kazakhstani and $64 \%$ of Kyrgyz female immigrants have the desire to do so.

Moldovan and Russian - $60 \%$ of Moldovan and $66 \%$ of Russian female immigrants have opportunities and $75 \%$ of Moldovan and $61 \%$ of Russian have the desire to do so.

Female immigrants from Tajikistan show that $50 \%$ of them have opportunities to continue their education and $100 \%$ of them have the desire to do so.

Turkmen, Ukrainian, and Uzbek - $27 \%$ of Turkmen, $51 \%$ of Ukrainian and $29 \%$ of Uzbek female immigrants have opportunities and $36 \%$ of Turkmen, $55 \%$ of Ukrainian and $71 \%$ of Uzbek female immigrants have the desire to do so.

\section{CONCLUSIONS}

I conclude that the educational level of female immigrants from the former Soviet Union in Turkey is a very high. The highest educational level is that of female immigrants from Lithuania $(17 \%$ of female immigrants were with a Ph.D. degree); Azerbaijan (14\%); Turkmenistan (10\%); Kazakhstan (8\%); Ukraine (5\%); Moldova (5\%); and Russia (4\%). In addition, $100 \%$ of the interviewed female immigrants from Armenia, Estonia, Latvia, and Tajikistan have a Graduate degree. The majority of the female immigrants from Azerbaijan; Belarus; Lithuania; Kazakhstan; 
Kyrgyzstan; Russia; Ukraine; Uzbekistan have a Graduate degree as well as half the female immigrants from Moldova.

However, only a small percentage of female immigrants are able to use their educational level in Turkey. According to results of surveys and semi-structured interviews, only $20 \%$ of Armenian female immigrants work in their own professions, $29 \%$ of Azerbaijani, $12 \%$ of Belarusian, $25 \%$ of Latvian, $17 \%$ of Lithuanian, $33 \%$ of Georgian, $23 \%$ of Kazakhstani, $18 \%$ of Kyrgyz, $15 \%$ of Moldovan, $18 \%$ of Russian, $27 \%$ of Turkmen, $16 \%$ of Ukrainian, and $14 \%$ of Uzbek female immigrants work in their own professions in Turkey.
In my opinion, human capital consists of basic and professional human capital and in cases when female immigrants cannot work in their professions in Turkey and cannot use their professional human capital, they can make use of their basic human capital by working in alternative or unskilled professions.

Restoration of their human capital may occur when they try to enter new professions, to gain recognition of their academic diplomas or to continue their education in Turkey but from their replies, I conclude that not all of them can study even if they have the desire to do so.

\section{WORKS CITED}

Arrazola, M. \& Hevia, J. (2004). More on the estimation of the human capital depreciation rate. Applied Economics Letters. 11(3), pp. 145-148.

Becker, G.S. (1993). Human Capital: A Theoretical and Empirical Analysis, with Special Reference to Education, $3 d$ edition. The University of Chicago Press, $412 \mathrm{p}$.

Becker G.S. (2016). Human Capital: A Theoretical and Empirical Analysis, with Special Reference to Education, 3d edition. University of Chicago Press. Retrieved from http://press.uchicago.edu/ucp/books/book/chicago/H/bo3684031.html

Hollenbeck, K. (1990). Dislocated Worker Human Capital Depreciation and Recovery. Upjohn Institute Working Paper No. 90-04. Kalamazoo, Mich.: W.E. Upjohn Institute for Employment Research. Retrieved from https://doi.org/10.17848/wp90-04.

Investopedia. (2016). Human Capital. Retrieved from http://www.investopedia.com/terms/h/humancapital.asp.

Koshulko, O. (2008). Human Capital Management in the Retail Food Industry. Manuscript. The dissertation on gaining the Economic Sciences Candidate degree in the specialty 08.00 .04 - economics and management of enterprises. National University of Food Technologies, Kyiv. Retrieved from http://library.nuft.edu.ua/ebook/file/kowylko_op.pdf

Koshulko, O. (2015a). Exploring of the Human Capital Depreciation of Ukrainian Labor Migrants Abroad: Results of a Survey, International Letters of Social and Humanistic Sciences, Vol. 64, pp. 66-72, Nov., SciPress Ltd., Bach, Switzerland, doi: 10.18052/www.scipress.com/ILSHS.64.66.

Koshulko, O., \& Onkal, G. (2015b). Issues in countries of the former Soviet Union as the driving force for female migration to Turkey. International Letters of Social and Humanistic Sciences, Vol. 56, pp. 120-126. Online: 2015-07-17. SciPress Ltd., Bach, Switzerland, doi: 10.18052/www.scipress.com/ILSHS.56.120.

Koshulko, O. (2016a). Women from North move to South: Contemporary migration from the Former Soviet Union countries to Turkey. Transnational Press London Ltd., UK, 126 p. ISBN 978-1-919781-31-9. Retrieved from http://www.tplondon.com/books/koshulko

Koshulko, O. (2016b). Discourse about Women-Immigrants from Former Soviet Union Countries as a Special Social Group in Turkey. In: Gender in Transnational Societies: Feminist Scholarship and Personal Narratives by Rujuta Chincholkar-Mandelia and Moiyattu Banya, pp. 165-167, Cognella Academic Publishing, San Diego, USA.

McFadden, D. (2008). Human Capital Accumulation and Depreciation. Applied Economic Perspectives and Policy. 30(3), pp. 379-385. doi: 10.1111/j.1467-9353.2008.00411.x 
Mincer, J. \& Ofek, H. (1982). Interrupted Work Careers: Depreciation and Restoration of Human Capital. The Journal of Human Resources, 17(1) (Winter, 1982), pp. 3-24, University of Wisconsin Press. DOI: $10.2307 / 145520$.

Schultz, T.W. (1961 March). Investment in Human Capital. The American Economic Review, 51(1). pp. 1-17.

Received for publication: $\quad 23.07 .2017$

Revision received: $\quad 20.09 .2017$

Accepted for publication: $\quad 10.01 .2018$

\section{How to cite this article?}

Style - APA Sixth Edition:

Koshulko, O. (2018, Jan 15). Human capital depreciation of female immigrants and ways to restore lost human capital. (Z. Čekerevac, Ed.) MEST Journal, 6(1), 27-33. doi:10.12709/mest.06.06.01.04

Style - Chicago Sixteenth Edition:

Koshulko, Oksana. 2018. "Human capital depreciation of female immigrants and ways to restore lost human capital." Edited by Zoran Čekerevac. MEST Journal (MESTE) 6 (1): 27-33. doi:10.12709/mest.06.06.01.04.

Style - GOST Name Sort:

Koshulko Oksana Human capital depreciation of female immigrants and ways to restore lost human capital [Journal] // MEST Journal / ed. Čekerevac Zoran. - Toronto : MESTE, Jan 15, 2018. - 1 : Vol. 6. pp. 27-33.

Style - Harvard Anglia:

Koshulko, O., 2018. Human capital depreciation of female immigrants and ways to restore lost human capital. MEST Journal, 15 Jan, 6(1), pp. 27-33.

Style - ISO 690 Numerical Reference:

Human capital depreciation of female immigrants and ways to restore lost human capital. Koshulko, Oksana. [ed.] Zoran Čekerevac. 1, Toronto : MESTE, Jan 15, 2018, MEST Journal, Vol. 6, pp. 27-33. 